\title{
Two-step hydrolysis of nipa (Nypa fruticans) frond as treated by semi- flow hot-compressed water
}

\section{AUTHOR(S):}

Phaiboonsilpa, Natthanon; Tamunaidu, Pramila; Saka, Shiro

\section{CITATION:}

Phaiboonsilpa, Natthanon ...[et al]. Two-step hydrolysis of nipa (Nypa fruticans) frond as treated by semi-flow hot-compressed water. Holzforschung 2011, 65(5): 659-666

\section{ISSUE DATE:}

2011-02

URL:

http://hdl.handle.net/2433/158041

RIGHT:

2011 Copyright (c) by Walter de Gruyter de Gruyter • Berlin • Boston 


\section{Two-step hydrolysis of nipa (Nypa fruticans) frond as treated by semi-flow hot-compressed water}

\author{
Natthanon Phaiboonsilpa, Pramila Tamunaidu and \\ Shiro Saka* \\ Graduate School of Energy Science, Kyoto University, \\ Yoshida-honmachi, Sakyo-ku, Kyoto 606-8501, Japan \\ * Corresponding author. \\ Department of Socio-Environmental Energy Science, Graduate \\ School of Energy Science, Kyoto University, Yoshida-honmachi, \\ Sakyo-ku, Kyoto 606-8501, Japan \\ E-mail: saka@energy.kyoto-u.ac.jp
}

\begin{abstract}
Two-step hydrolysis of nipa (Nypa fruticans) frond, one of the monocotyledonous angiosperms, was studied in a semiflow hot-compressed water treatment at $230^{\circ} \mathrm{C} / 10 \mathrm{MPa} /$ $15 \mathrm{~min}$ (first stage) and $270^{\circ} \mathrm{C} / 10 \mathrm{MPa} / 30 \mathrm{~min}$ (second stage). In the first stage, hemicelluloses such as $O$-acetyl-4$O$-methylglucuronoarabinoxylan and pectin and para-crystalline cellulose were selectively hydrolyzed, as well as lignin, which was partially decomposed. In the second stage, hydrolysis of crystalline cellulose and some additional decomposition of lignin were observed. In addition, inorganic constituents and free sugars, composed mainly of glucose, fructose, and sucrose, were recovered in cold water $\left(20^{\circ} \mathrm{C} /\right.$ $10 \mathrm{MPa} / 30 \mathrm{~min}$ ) prior to these 2 stages. In total, $97.3 \%$ of oven-dried nipa frond sample could be solubilized into cold and hot-compressed water. The degradation products in the water-soluble portion were primarily recovered as various saccharides (hydrolyzed moieties of the polyoses), which were later dehydrated, fragmented and isomerized partly. The residual $(2.7 \%)$ is composed mainly of lignin associated with $0.4 \%$ of $\mathrm{Si}$. A decomposition pathway is proposed for $O$-acetyl-4- $O$-methylglucuronoarabinoxylan as the major hemicellulose based on its various hydrolyzed products.
\end{abstract}

Keywords: cellulose; frond; hemicelluloses; hot-compressed water; lignin; nipa.

\section{Introduction}

Nipa (Nypa fruticans) is one of the most useful and versatile palms in the restricted mangrove forests of Southeast Asia and Oceania. Its leaves, fruit, and juice or sap from its inflorescence stalk (peduncle) are a source of products for indigenous people living near this region since historical times (Hamilton and Murphy 1988). Figure 1 illustrates various parts of the nipa palm.
From the taxonomic viewpoint, nipa belongs to monocotyledonous angiosperms (monocots) and as such it is considered as a non-woody plant because of its difference in anatomy and lack of vascular cambium. However, based on their chemical composition, the monocots are lignocellulosic materials. Similar to other palms, the lignocellulosic tissues of nipa are different in the frond, leaves, fruit, etc., which are under investigation currently in our laboratory. The lignocellulosic material of its frond has a potential for biochemicals and biofuels because of its chemical composition (cellulose, hemicelluloses, and lignin). The frond also contains proteins, starch, extractives, and inorganic constituents.

In our previous works ( $\mathrm{Lu}$ et al. 2009; Phaiboonsilpa et al. 2010), a two-step hydrolysis of Japanese beech (Fagus crenata) and Japanese cedar (Cryptomeria japonica) was described, in the course of which the materials are treated in a semi-flow equipment with hot-compressed water ( $\mathrm{H}-\mathrm{CW})$.

The treatment of biomass with hot water has a long tradition, mostly as a pretreatment method to improve dissolved pulp production (Al-Dajani and Tschirner 2010) or enzymatic hydrolysis of biomass (Liu and Wyman 2005; Mosier et al. 2005; Cara et al. 2008), and also aiming at the production of chemicals (biorefinery) with water under subcritical and supercritical conditions (Mok and Antal 1992; Kabyemela et al. 1997a; Ando et al. 2000; Sasaki et al. 2002; Yu et al. 2008; Liu 2010). The process is termed hydrothermolysis, if high temperatures (and necessarily high pressures) are applied. Early efforts with this regard are summarized by Bonn et al. (1983).

Hemicelluloses and cellulose were found to hydrolyze uniformly in the first and second stages of the treatment in the semi-flow reactor constructed in our laboratory, while lignin was partially decomposed to some extent, mainly in the first stage. Various hydrolyzed (only mildly changed) and more or less heavily decomposed substances from the cell wall were obtained and identified.

In the present study, the two-step hydrolysis procedure was applied for nipa frond to gain insights into the behavior of monocots in hot-compressed water. As in the previous studies, qualitative and quantitative analyses will be performed on the various products obtained. Chemical conversion of nipa frond under the treatment conditions will be discussed and decomposition pathways of hemicelluloses will be proposed.

\section{Materials and methods}

Nipa (Nypa fruticans) frond was collected from Pak Phanang, Nakorn Si Thammarat, Thailand. The frond was milled as usual in 


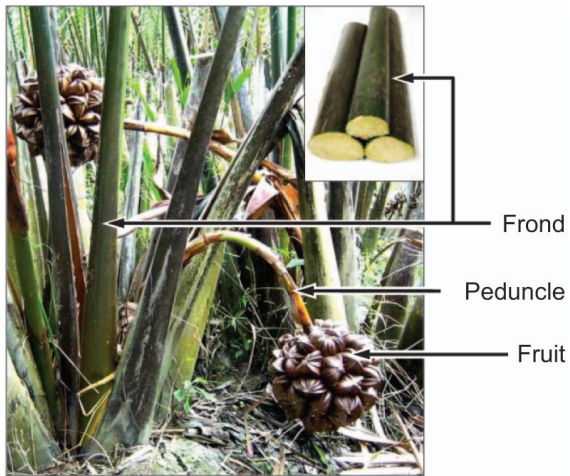

Figure 1 Nipa palm consisting of fronds with fruits.

wood chemistry and sieved to the size $<1 \mathrm{~mm}$. The fines $(<150 \mu \mathrm{m})$ were rejected. The sieved material was dried at $105^{\circ} \mathrm{C}$ for $12 \mathrm{~h}$ and kept in a desiccator. All chemicals were of reagent grade and used without purification.

The material was extracted with EtOH/benzene $1 / 2$ by vol. for $24 \mathrm{~h}$ and dried. Then the material was suspended in hot water $\left(60^{\circ} \mathrm{C}\right)$ at atmospheric pressure under vigorous stirring for $2 \mathrm{~h}$ to remove some other remaining polar extractives left after the previous extraction step. The solid material was filtrated and dried.

Table 1 shows the results of quantitative chemical analysis obtained by the methods described by Lu et al. (2009) and Phaiboonsilpa et al. (2010). Protein was quantified by the Kjeldahl method (Tomomatsu et al. 1996; AOAC Official Method 2001), and starch content through colorimetry according to Humphreys and Kelley (1961). The free sugar content of the hot-water extractives was analyzed by HPAEC (ICS-3000, Dionex) and its inorganic constituents were quantified by incinerating in a muffle furnace at $600^{\circ} \mathrm{C}$ for $4 \mathrm{~h}$ (Table 2 ).

The EtOH/benzene-extracted material was also treated with distilled water at room temperature (ca. $20^{\circ} \mathrm{C}$ ) in the semi-flow reactor; flow-rate $10 \mathrm{ml} \mathrm{min}^{-1}$; pressure $10 \mathrm{MPa}$; time $30 \mathrm{~min}$. As seen from Table 2, the yields of free sugars and inorganic constituents were comparable to those conducted by the hot-water extraction $\left(60^{\circ} \mathrm{C} /\right.$ $0.1 \mathrm{MPa} / 2 \mathrm{~h}$ ). Accordingly, the hot-water extraction step could then be omitted. The cold-water extractives were analyzed with the same methods as the hot-water extractives.

Table 1 Chemical composition of nipa frond. Percentage data based on weight of oven-dried raw material ${ }^{\text {a }}$.

\begin{tabular}{lr}
\hline \multicolumn{1}{c}{ Component } & $\begin{array}{c}\text { Yield } \\
(\%)\end{array}$ \\
\hline Hemicelluloses & 18.9 \\
Cellulose & 25.6 \\
Lignin & 23.7 \\
Protein & 2.4 \\
Starch & 0.8 \\
Extractives in & \\
$\quad$ EtOH/benzene & 1.8 \\
Hot water & 26.0 \\
Inorganics & 2.9 \\
Total & 102.1 \\
\hline
\end{tabular}

anorganic constituents in the material extracted by EtOH/benzene and hot water.
Table 2 Chemical composition of extractives in hot water $\left(60^{\circ} \mathrm{C} /\right.$ $0.1 \mathrm{MPa} / 2 \mathrm{~h})$ and cold water $\left(20^{\circ} \mathrm{C} / 10 \mathrm{MPa} / 30 \mathrm{~min}\right)$ from nipa frond (wt\% on oven-dried frond basis) ${ }^{\mathrm{a}, \mathrm{b}}$.

\begin{tabular}{lcc}
\hline & \multicolumn{2}{c}{ Extractives in } \\
\cline { 2 - 3 } \multicolumn{1}{c}{ Component } & Hot water & Cold water \\
\hline Nipa frond sap & & \\
$\quad$ Glucose & 1.0 & 0.9 \\
Fructose & 0.5 & 0.4 \\
$\quad$ Sucrose & 0.1 & 0.1 \\
Other sugars $^{\mathrm{a}}$ & 0.1 & 0.1 \\
Unknown $_{\text {Inorganics }}^{\mathrm{b}}$ & 16.9 & 16.5 \\
Total & 7.4 & 7.4 \\
\hline
\end{tabular}

a Other sugars: galactose, mannose, rhamnose, and arabinose. bInorganic constituents recovered by hot-water and cold-water extraction.

\section{Treatment with $\mathrm{H}-\mathrm{CW}$ and fractionation of the products}

The semi-flow system and its operational procedures were described by $\mathrm{Lu}$ et al. (2009). In brief, approximately $0.5 \mathrm{~g}$ of oven-dried nipa frond sample was placed in the reactor and treated with cold water followed by two-step hot-compressed water (H-CW) (for fractionation see Figure 2).

Solubles in cold water and $\mathrm{H}-\mathrm{CW}$ were collected by the fraction collector every $1 \mathrm{~min}$. Soluble portion in $\mathrm{H}-\mathrm{CW}$ was left at the ambient temperature and under atmospheric pressure for $12 \mathrm{~h}$; the liquid was then filtrated over a $0.2-\mu \mathrm{m}$ membrane prior to subsequent analyses. The solid residue was oven-dried and analyzed.

\section{Analyses of products}

The water-soluble portion was analyzed by HPAEC, HPLC, GCMS, and capillary electrophoresis (CE) as described by Lu et al. (2009) and Phaiboonsilpa et al. (2010). The product percentages, presented on oven-dried weight basis of the initial material, are based on the chromatogram peak areas of the HPAEC, HPLC, CE, and GC-MS (Figures 3 and 4).

Ashes (obtained as described above) were characterized by means of energy-dispersive X-ray (EDX) spectroscopy. Scanning electron microscope (SEM, JSM-5800, JEOL Ltd) equipped with an EDX spectroscopic instrument (EDAX Corp., Phoenix) was employed at an accelerating voltage of $15 \mathrm{kV}$ (Figure 5).

\section{Results and discussion}

\section{Free sugars and inorganics in cold-water extractives}

In contrast to woods, a significant amount of free sugars and inorganic constituents has been found in the water extractives (Tables 1 and 2). Figure 3 shows the temperature profile of the treatment and the yields of the free sugars: glucose, fructose, sucrose, mannose, arabinose, galactose, and rhamnose, in cold water ( -30 to $-10 \mathrm{~min}$ ). Obviously, glucose was the dominant free sugar, followed by fructose, sucrose and other monosaccharides. In oil palm trunks, similar free sugars were found (Kosugi et al. 2010).

Over $70 \%$ of total inorganic contents in nipa frond could be recovered in the cold-water extractives (Table 3), while 


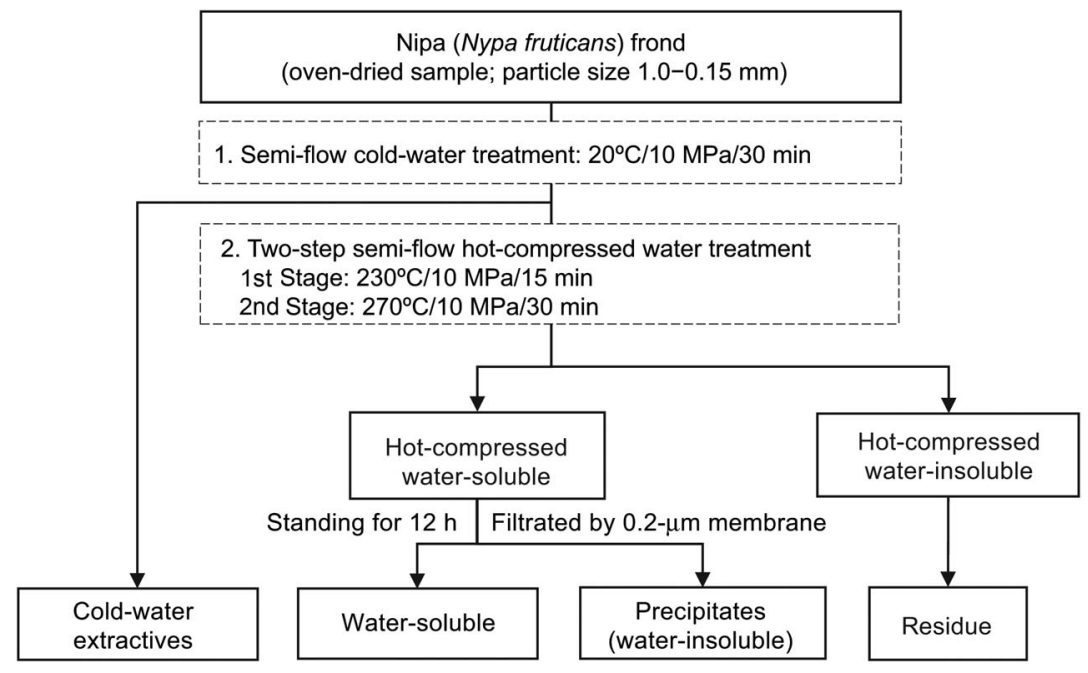

Figure 2 Fractionation process of nipa frond as treated in a semi-flow reactor with two-step hot-compressed water at $10 \mathrm{MPa}$.

approximately $23 \%$ was dissolved in the first stage hot-compressed water treatment and no ash was found in the second stage. The remaining 4\% was left in the solid residue. Accordingly, the balance of inorganic components was satisfactory with an almost $100 \%$ recovery rate. On the other hand, from $25.4 \%$ of cold-water extractives, only $8.9 \%$ were found to be free sugars and inorganic constituents (Table 2). The other $16.5 \%$ are not yet identified.

\section{Hydrolysis of major cell wall components}

The two-step $\mathrm{H}-\mathrm{CW}$ treatment (first, $230^{\circ} \mathrm{C} / 10 \mathrm{MPa} / 15 \mathrm{~min}$ and second, $270^{\circ} \mathrm{C} / 10 \mathrm{MPa} / 30 \mathrm{~min}$ ) in a semi-flow reactor, liquefied $97.3 \%$ of the material. The solid residue left $(2.7 \%)$ consisted mainly of $2.3 \%$ lignin with $0.4 \%$ inorganics.

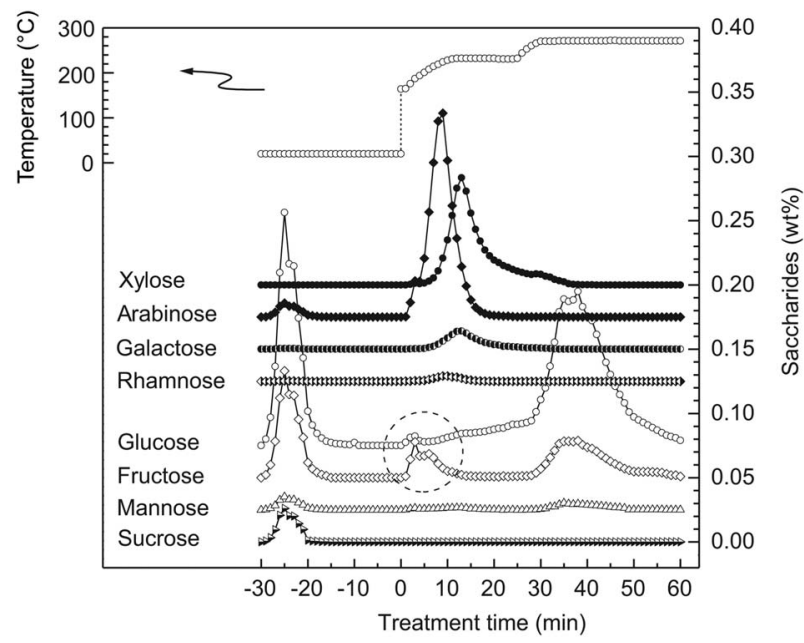

Figure 3 Saccharides from nipa frond as treated in a semi-flow reactor with cold water at $20^{\circ} \mathrm{C} / 10 \mathrm{MPa} / 30$ min followed by twostep hot-compressed water at $230^{\circ} \mathrm{C} / 10 \mathrm{MPa} / 15 \mathrm{~min}$ and $270^{\circ} \mathrm{C} / 10$ $\mathrm{MPa} / 30 \mathrm{~min}$. Dashed circle indicates the production of glucose and fructose from free sugars incompletely removed by cold-water extraction.
The following xylo-saccharides were obtained in the first stage (Figure 4a): xylose and xylo-oligosaccharides, such as xylobiose, xylotriose, xylotetraose, xylopentaose, xylohexaose, and the molecules with higher degree of polymerization (DP). Moreover, arabinose, acetic acid, glucuronic acid, methanol and galacturonic acid were detected. These products are possibly from $O$-acetyl-4- $O$-methylglucuronoarabinoxylan, which is the major hemicellulose found in monocotyledonous angiosperms, particularly in palms, while galacturonic acid is from pectin (Suzuki et al. 1998; Scheller and Ulvskov 2010). In addition, hydrolyzed monomeric guaiacyl and syringyl units from lignin, such as coniferyl alcohol and sinapyl alcohol, were obtained in this stage.

Based on the yields of hydrolyzed products obtained (Table 4), $\mathrm{O}$-acetyl-4- $\mathrm{O}$-methylglucuronoarabinoxylan contains acetic acid, glucuronic acid, arabinose and xylose residues in a molar ratio of 0.13/0.001/0.37/1. Different compound ratios were determined by Suzuki et al. (1998) for oil palm frond (0.40/0.04/0.07/1). Accordingly, nipa frond contains over five times more of arabinose than oil palm frond, while acetyl and glucuronic residues in nipa frond are relatively low. This might be mainly due to the genetic variations between the plant species and the environmental conditions under which they have grown. The ratio of methanol and glucuronic acid was found to be in the present study $0.6 / 1$ in 4- $O$-methylglucuronosyl residues.

As for glucose and cello-oligosaccharides, such as cellobiose, cellotriose, etc. including the fragments with higher $\mathrm{DP}$, were produced throughout the whole $60 \mathrm{~min}$ of the twostep treatment (Figure 4a). Products from the first stage (1-25 min) were derived from glucomannan in hemicelluloses and para-crystalline cellulose (with disordered crystallinity), while the rest in the second stage (25-60 min) from crystalline cellulose. Our studies on woods resulted in similar results (Lu et al. 2009; Phaiboonsilpa et al. 2010). Para-crystalline cellulose of wood was found to be readily hydrolyzed at the same treatment conditions in the first stage.

The production trends of monosaccharides are displayed in Figure 3. All hemicelluloses-derived monosaccharides 

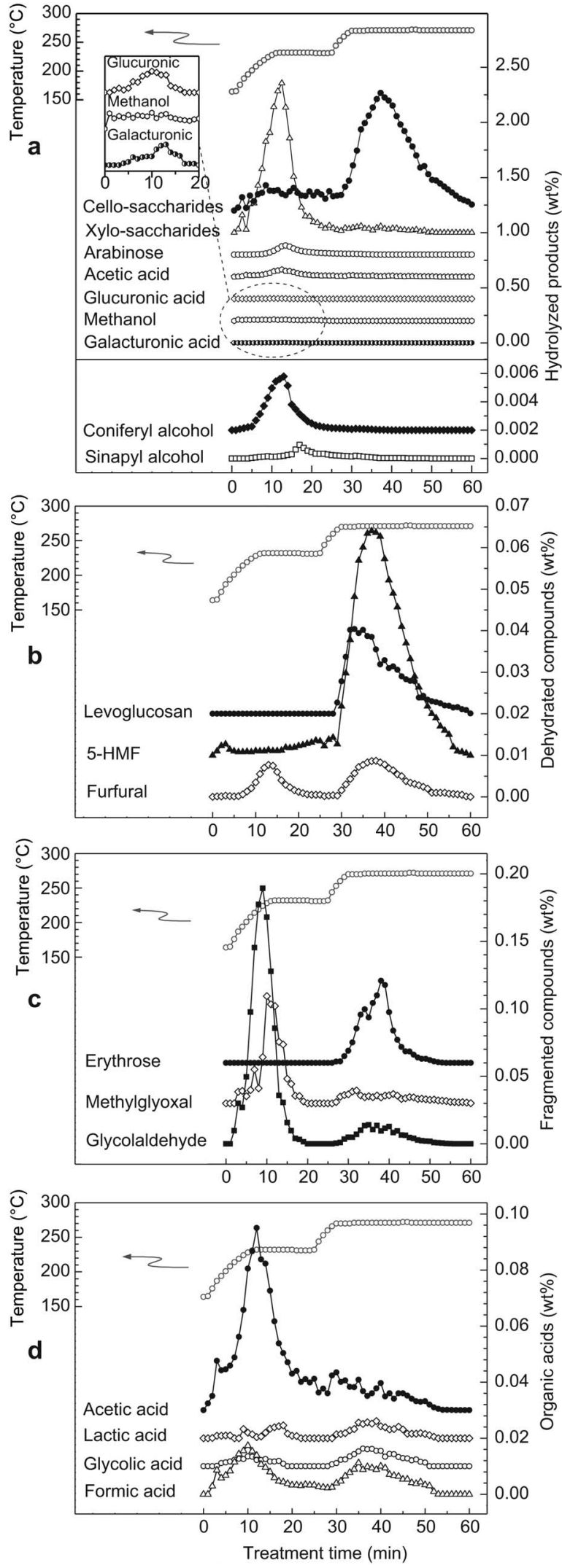

(xylose, arabinose, galactose, rhamnose, and glucose) arise in the first stage, while glucose released in the second stage is from the hydrolysis of cellulose. Arabinan units are obvi-
Figure 4 Yield of various products of nipa frond as a function of treatment time in a two-step hot-compressed water treatment using a semi-flow reactor. First stage: $230^{\circ} \mathrm{C} / 10 \mathrm{MPa} / 15 \mathrm{~min}$. Second stage: $270^{\circ} \mathrm{C} / 10 \mathrm{MPa} / 30 \mathrm{~min}$. (a) Products of hydrolysis. Inserted figure is the enlargements of the glucuronic acid, methanol, and galacturonic acid peaks in the first stage. (b) Dehydrated compounds. (c) Fragmented compounds. (d) Organic acids.

ously hydrolyzed faster and recovered as arabinose in greater yield. The relatively high susceptibility of arabinose in wood hemicelluloses to acid hydrolysis is well known (Rydholm 1965; Fengel and Wegener 1984; Sano et al. 1989).

Fructose and mannose were formed as isomerized compounds of glucose in the second stage (25-60 min) as reported previously ( $\mathrm{Lu}$ et al. 2009; Phaiboonsilpa et al. 2010). However, a significant amount of fructose appeared at a very early treatment time (1-10 min) in the first stage. As fructose is not a component in hemicelluloses, it must originate from the remaining free sugars left after cold-water extraction (Table 2). Fructose might also be bound with the cell wall components. It should be noted that a small peak of glucose after $0-5$ min is also observed.

\section{Degradation products from hemicelluloses and cellulose}

The yields of levoglucosan, 5-HMF, and furfural (Figure 4b) as a function of treatment time are easy to interpret. As hemicelluloses in nipa frond are mainly composed of pentoses, furfural was predominantly produced from xylose in the first stage. In the second stage the yield of furfural and 5-HMF increased due to more severe conditions. Levoglucosan as a monodehydrated glucose was detected exclusively in the second stage. Similar findings were reported by Lu et al. (2009) and Phaiboonsilpa et al. (2010).

5-HMF generated at a very early treatment time (1-10 min) can be attributed to the dehydration of fructose and

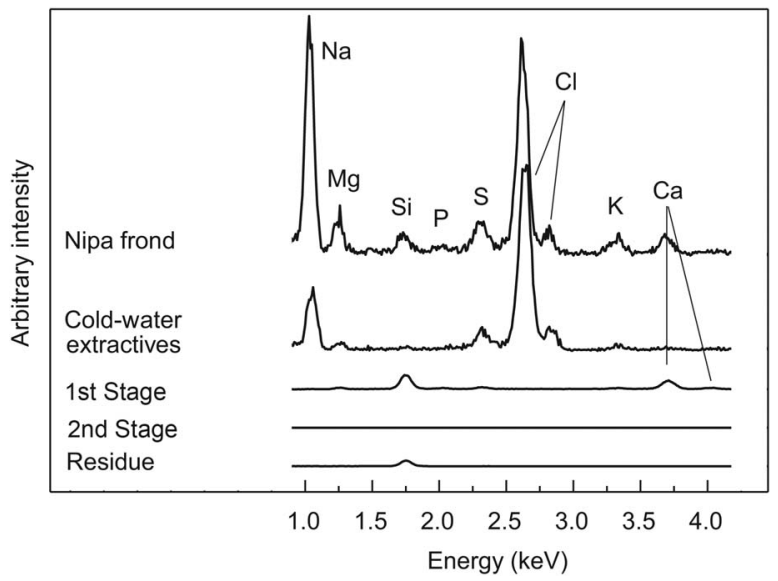

Figure 5 Comparison of EDX spectra of inorganic constituents in ashes of nipa frond, obtained in cold-water extractives, first and second stage hot-compressed water-soluble portions, as well as residue. 
Table 3 Yields of inorganic constituents in various fractionated portions of nipa frond (wt $\%$ on oven-dried frond basis). First stage: $230^{\circ} \mathrm{C} / 10 \mathrm{MPa} / 15 \mathrm{~min}$; second stage: $270^{\circ} \mathrm{C} / 10 \mathrm{MPa} / 30 \mathrm{~min}^{\mathrm{a}}$.

\begin{tabular}{lcccccc}
\hline & \multirow{2}{*}{$\begin{array}{c}\text { Soluble in } \\
\text { cold water }\end{array}$} & \multicolumn{2}{l}{ Soluble in hot-compressed water } & & In solid & \\
\cline { 3 - 4 } & & First stage & Second stage & & residue & Total \\
\hline Based on raw material $(\%)$ & 7.4 & 2.4 & 0.0 & 0.4 & 10.2 \\
Based on inorganic con. $(\%)^{\mathrm{a}}$ & 71.8 & 23.3 & 0.0 & 3.9 & 99.0 \\
\hline
\end{tabular}

${ }^{a}$ Relative $\%$ based on the total inorganic contents obtained in each fraction. Total inorganic constituents based on nipa frond $10.3 \%$.

Table 4 Summarized yields of products from nipa frond as treated in a semi-flow reactor with cold water at $20^{\circ} \mathrm{C} / 10 \mathrm{MPa} / 30 \mathrm{~min}$ followed by two-step hot-compressed water at $230^{\circ} \mathrm{C} / 10 \mathrm{MPa} / 15 \mathrm{~min}$ and $270^{\circ} \mathrm{C} / 10 \mathrm{MPa} / 30 \mathrm{~min}^{\mathrm{a}-\mathrm{g}}$.

\begin{tabular}{|c|c|c|c|c|c|c|c|c|}
\hline \multirow[b]{3}{*}{ Products } & \multicolumn{7}{|c|}{ Yield (wt $\%$ on oven-dried frond basis) } & \multirow[b]{3}{*}{ Total } \\
\hline & \multirow[b]{2}{*}{$\begin{array}{l}\text { Cold-water } \\
\text { extractives }\end{array}$} & \multicolumn{3}{|c|}{ First stage } & \multicolumn{3}{|c|}{ Second stage } & \\
\hline & & $\begin{array}{l}\text { Hemi- } \\
\text { celluloses }\end{array}$ & Cellulose & Lignin & $\begin{array}{l}\text { Hemi- } \\
\text { celluloses }\end{array}$ & Cellulose & Lignin & \\
\hline Free sugars & 1.5 & - & - & - & - & - & - & 1.5 \\
\hline \multicolumn{9}{|l|}{ From hydrolysis of hemis and cell. } \\
\hline$\sum$ & - & 20.1 & 3.7 & - & 0.2 & 17.9 & - & 41.9 \\
\hline Xylo-saccharides & - & 11.4 & - & - & $0.2^{\mathrm{e}}$ & - & - & 11.6 \\
\hline Arabinose & - & 4.3 & - & - & - & - & - & 4.3 \\
\hline Acetic acid & - & 0.6 & - & - & - & $0.2^{\mathrm{f}}$ & - & 0.8 \\
\hline Glucuronic acid & - & 0.02 & - & - & - & - & - & 0.02 \\
\hline Methanol & - & 0.002 & - & - & - & - & - & 0.002 \\
\hline Galactose & - & 1.3 & - & - & - & - & - & 1.3 \\
\hline Rhamnose & - & 0.4 & - & - & - & - & - & 0.4 \\
\hline Mannose & - & 1.3 & - & - & - & $0.4^{\mathrm{g}}$ & - & 1.7 \\
\hline Galacturonic acid & - & $0.03^{\mathrm{a}}$ & - & - & - & - & - & 0.03 \\
\hline Cello-saccharides & - & $0.7^{\mathrm{b}}$ & $3.6^{\mathrm{c}}$ & - & - & 16.9 & - & 21.2 \\
\hline Fructose & - & - & $0.1^{\mathrm{d}}$ & - & - & $0.4^{\mathrm{g}}$ & - & 0.5 \\
\hline \multicolumn{9}{|l|}{ From lignin } \\
\hline$\sum$ & - & - & - & 17.9 & - & - & 3.6 & 21.5 \\
\hline Coniferyl alcohol & - & - & - & 0.03 & - & - & 0.01 & 0.04 \\
\hline Sinapyl alcohol & - & - & - & 0.01 & - & - & 0.00 & 0.01 \\
\hline Dimeric, trimeric and olig. products & - & - & - & 17.9 & - & - & 3.6 & 21.5 \\
\hline \multicolumn{9}{|l|}{ Dehydrated compd } \\
\hline$\sum$ & - & 0.1 & - & - & - & 1.1 & - & 1.2 \\
\hline Levoglucosan & - & 0.0 & - & - & - & 0.3 & - & 0.3 \\
\hline 5-HMF & - & 0.0 & - & - & - & 0.7 & - & 0.7 \\
\hline Furfural & - & 0.1 & - & - & - & 0.1 & - & 0.2 \\
\hline \multicolumn{9}{|l|}{ Fragmented compd } \\
\hline$\sum$ & - & 1.7 & - & - & - & 0.7 & - & 2.4 \\
\hline Methylglyoxal & - & 0.5 & - & - & - & 0.1 & - & 0.6 \\
\hline Glycolaldehyde & - & 1.2 & - & - & - & 0.2 & - & 1.4 \\
\hline Erythrose & - & - & - & - & - & 0.4 & - & 0.4 \\
\hline \multicolumn{9}{|l|}{ Organic acids } \\
\hline$\sum$ & - & 0.2 & - & - & - & 0.4 & - & 0.6 \\
\hline Lactic acid & - & 0.0 & - & - & - & 0.1 & - & 0.1 \\
\hline Glycolic acid & - & 0.0 & - & - & - & 0.1 & - & 0.1 \\
\hline Formic acid & - & 0.2 & - & - & - & 0.2 & - & 0.4 \\
\hline Inorganics & 7.4 & 2.4 & - & - & - & 0.0 & - & 9.8 \\
\hline Total & 8.9 & 24.5 & 3.7 & 17.9 & 0.2 & 20.1 & 3.6 & 78.9 \\
\hline Unknown & & & & & & & & 18.4 \\
\hline Water-insol. residue & & & & & & & & 2.7 \\
\hline
\end{tabular}

${ }^{\mathrm{a}}$ Galacturonic acid from pectin. ${ }^{\mathrm{b}} \mathrm{Glucose}$ from glucomannan. ${ }^{\mathrm{c} C e l l o-s a c c h a r i d e s ~ f r o m ~ p a r a-c r y s t a l l i n e ~ c e l l u l o s e . ~}{ }^{\mathrm{d}}$ Fructose from free sugars

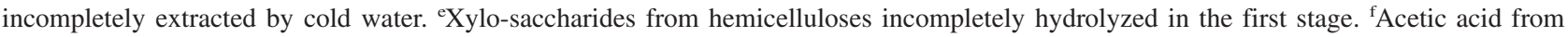

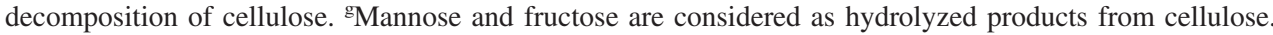


glucose present in the free sugar forms. On the contrary, its later production between 10-25 min can be explained by the decomposition of glucose obtained from hydrolysis of glucomannan and para-crystalline cellulose.

As for the heavily fragmented compounds, Figure 4c shows that methylglyoxal and glycolaldehyde were produced in both first and second stages, while erythrose was formed in the second stage only. In the first stage, it is likely that pentoses such as xylose and arabinose from hemicelluloses would be decomposed to glycolaldehyde and glyceraldehyde, and then glyceraldehyde would be dehydrated to methylglyoxal as observed in glyceraldehyde pathway of hexose fragmentation (Kabyemela et al. 1997b).

In the second stage, glycolaldehyde and erythrose were formed via retro-aldol condensation in the glycolaldehyde/ erythrose pathway (Kabyemela et al. 1997c; Kabyemela et al. 1999), while methylglyoxal arises probably via the glyceraldehyde/dihydroxyacetone pathway of hexose fragmentation (Kabyemela et al. 1999; Watanabe et al. 2005). However, under the conditions applied, glyceraldehyde and its isomerized dihydroxyacetone as part of the glyceraldehyde pathway were not detected. This is probably due to the fast dehydration reaction of glyceraldehyde to methylglyoxal and/or organic acids (Kabyemela et al. 1997b). Similar decomposition and fragmented compounds were observed in a study on Japanese beech (Lu et al. 2009).

\section{Production of organic acids}

As shown in Figure 4d, the produced organic acids are acetic, lactic, glycolic, and formic acids. The origin of acetic acid in the first stage is the acetyl groups of hemicelluloses. On the other hand, acetic acid from the second stage must be a result of decomposition of cellulose and/or lignin (Yoshida et al. 2005; Lu et al. 2009; Phaiboonsilpa et al. 2010). In addition, the production of lactic, glycolic, and formic acids, observed in both stages of the treatment, indicates that decomposition of dehydrated and fragmented compounds took place. Acrylic acid and levulinic acid were not detected.

\section{Products from hemicelluloses, cellulose and lignin}

The results of this study are summarized in Table 4. It can be seen that the water-soluble portion contains $41.7 \%$ hydrolyzed products as various saccharides, uronic acids, methanol, and acetic acid. The detailed quantification is: $20.3 \%$ $(=20.1 \%+0.2 \%)$ are from hemicelluloses and $21.4 \%$ $(=3.7 \%+17.9 \%-0.2 \%)$ are from cellulose. In addition, $21.5 \%$ lignin-derived products are obtained, mainly in oligomeric forms. As for the decomposed compounds, $4.4 \%$ including $1.2 \%$ from dehydrated compounds, $2.4 \%$ from fragmented compounds, and $0.8 \%(=0.6 \%+0.2 \%)$ from organic acids are realized. Moreover, $1.5 \%$ free sugars and

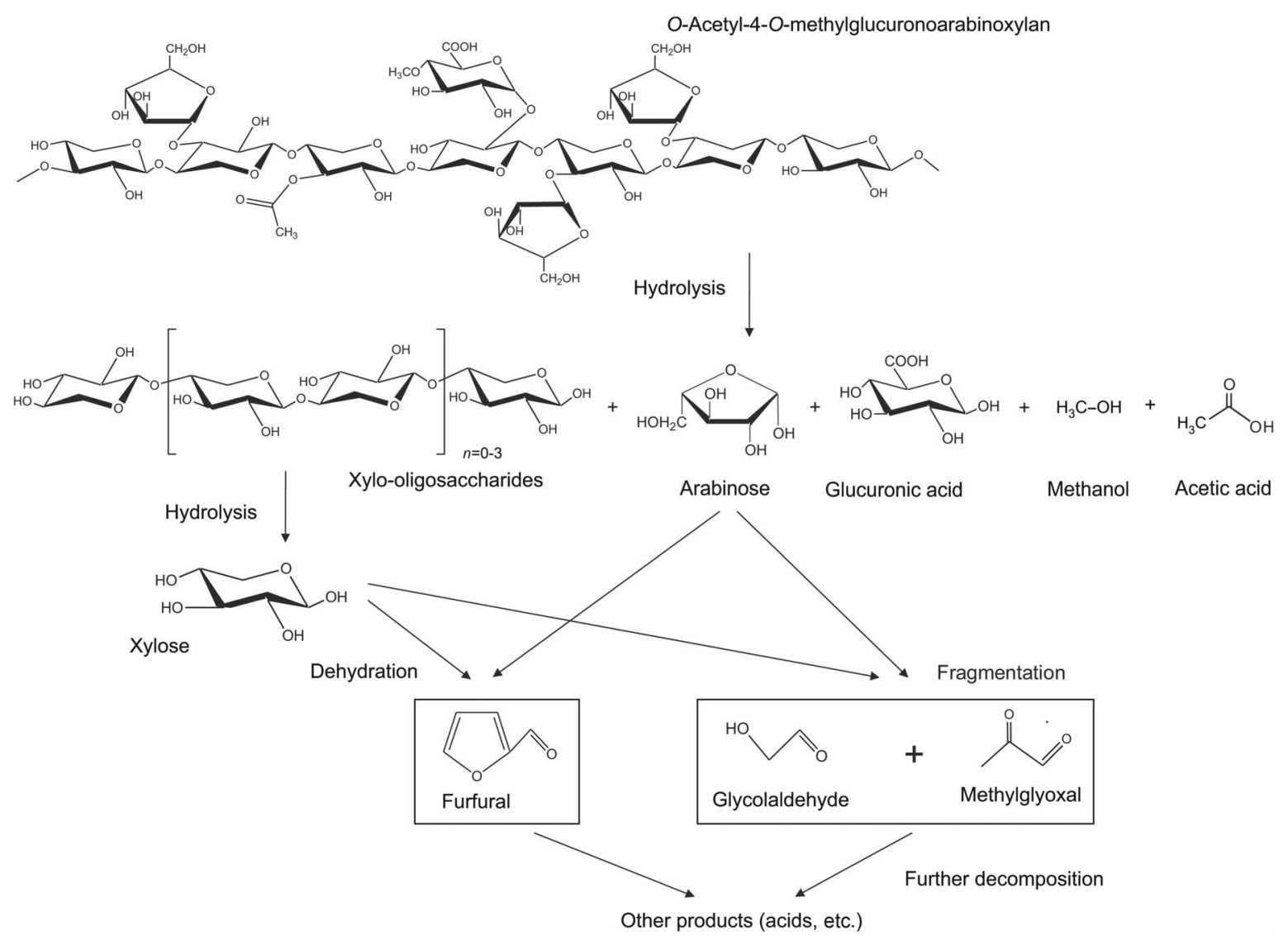

Figure 6 Proposed decomposition pathway of $O$-acetyl-4- $O$-methylglucuronoarabinoxylan in nipa frond as treated in a semi-flow reactor with two-step hot-compressed water at $230^{\circ} \mathrm{C} / 10 \mathrm{MPa} / 15 \mathrm{~min}$ and $270^{\circ} \mathrm{C} / 10 \mathrm{MPa} / 30 \mathrm{~min}$. 
$9.8 \%$ inorganic constituents were recovered. The rest $18.4 \%$ are unidentified products in the water-soluble portion.

Nipa frond consists of $18.9 \%$ hemicelluloses, $25.6 \%$ cellulose, and $23.7 \%$ lignin (Table 1). Hemicelluloses were hydrolyzed approximately to an extent of $107.4 \%[=(20.1+$ $0.2) / 18.9 \times 100 \%]$, cellulose to $83.6 \%[=(3.7+17.9-0.2) /$ $25.6 \times 100 \%]$, and lignin to $90.7 \%[=(17.9+3.6) / 23.7 \times$ $100 \%]$ in the two-step hot-compressed water treatment. If the yield of hydrolyzed products of hemicelluloses is calculated on the anhydrosugar basis, the sum of the percentage will be lower than $100 \%$.

\section{Inorganic constituents in the fractions}

The EDX spectra of inorganic constituents dissolved in coldwater and in the two steps of hot-compressed water treatment and of the solid residue are presented in Figure 5. In nipa frond the elements $\mathrm{Na}, \mathrm{Mg}, \mathrm{Si}, \mathrm{P}, \mathrm{S}, \mathrm{Cl}, \mathrm{K}$, and $\mathrm{Ca}$ were detected. These elements are present as parts of salts in oxalates, carbonates, and sulfates, but they can also be bound to cell wall components such as carboxyl groups of hemicelluloses or pectic materials (Saka 2001). Cl is exclusively present in salts, as they can be simply removed by dissolving in cold water, while $\mathrm{Na}, \mathrm{Mg}, \mathrm{P}, \mathrm{S}, \mathrm{K}$, and $\mathrm{Ca}$ probably occur in both forms. On the other hand, Si is certainly part of silica. It was partially removed by hot-compressed water in the first stage treatment and the rest remained in the solid residue.

\section{Decomposition pathway of hemicelluloses}

The hydrolysis of cellulose and hemicelluloses is well described such as the formation of furfural and 5-HMF and the formation of low molecular weight components under harsh conditions (Timell 1967; Fengel and Wegener 1984; Ehara and Saka 2002; Lu et al. 2009; Scheller and Ulvskov 2010). Nevertheless, a schematic overview is useful to summarize the essential results of this study. In Figure 6 the decomposition of $O$-acetyl-4- $O$-methylglucuronoarabinoxylan is illustrated to xylose, xylo-oligosaccharides, arabinose, glucuronic acid, methanol, and acetic acid. Galacturonic acid is not included in this scheme because it is considered as a constituent of pectin (Scheller and Ulvskov 2010). The dehydration reaction could be confirmed as furfural from pentoses (xylose and arabinose) was detected in the first stage, while the formation of the fragmented compounds (glycolaldehyde and methylglyoxal) could be attributed to the fragmentation reaction of these pentoses. The further decomposition of these compounds leads to the various organic acids observed at this stage.

\section{Conclusions}

Hemicelluloses and crystalline cellulose of nipa frond can be hydrolyzed separately by a two-step hot-compressed water $(\mathrm{H}-\mathrm{CW})$ treatment in a semi-flow system. Lignin was partially decomposed. Galacturonic acid was detected from the hydrolysis of pectin. Free sugars and inorganic constituents are released under the conditions of the treatment. The yields of degradation products as a function of elution time permit the interpretation of the locations and connectivity of the molecules degraded in the plant cell wall. The industrial realization of biomass fractionation in $\mathrm{H}-\mathrm{CW}$ is hampered by the recovery of compounds from water, in which they are present in high dilution. Nevertheless, the data on the hydrolytic decomposition behavior of the monocotyledonous angiosperm nipa frond may contribute to the idea of biorefinery, i.e., production of biochemicals and biofuels, of this type of biomass.

\section{Acknowledgements}

This work has been done as in part of the NEDO project (FYs 2007-2010), "Eco-ethanol production from lignocellulosics with hot-compressed water treatment followed by acetic acid fermentation and hydrogenolysis'. Partial financial supports from the Global Center of Excellence (GCOE) Program, Kyoto University, and the Kansai Electric Power Co. Inc., Osaka, are highly acknowledged.

\section{References}

Al-Dajani, W.W., Tschirner, U.W. (2010) Pre-extraction of hemicelluloses and subsequent ASA and ASAM pulping: comparison of autohydrolysis and alkaline extraction. Holzforschung 64:411-416.

Ando, H., Sakaki, T., Kokusho, T., Shibata, M., Uemura, Y., Hatate, Y. (2000) Decomposition behavior of plant biomass in hot-compressed water. Ind. Eng. Chem. Res. 39:3688-3693.

AOAC Official Method (2001) Crude protein in animal feed, forage, grain, and oilseeds, block digestion using copper catalyst, steam distillation into boric acid. AOAC International, Gaithersburg, MD.

Bonn, G., Concin, R., Bobleter, O. (1983) Hydrothermolysis - a new process for the utilization of biomass. Wood Sci. Technol. 17:195-202.

Cara, C., Ruiz, E., Oliva, J.M., Sáez, F., Castro, E. (2008) Converstion of olive tree biomass into fermentable sugars by dilute acid pretreatment and enzymatic saccharification. Bioresource Technol. 99:1869-1876.

Ehara, K., Saka, S. (2002) A comparative study on chemical conversion of cellulose between the batch-type and flow-type systems in supercritical water. Cellulose 9:301-311.

Fengel, D., Wegener, G. Wood: Chemistry, Ultrastructure, Reactions. Walter de Gruyter, Berlin, 1984.

Hamilton, L.S., Murphy, D.H. (1988) Use and management of nipa palm (Nypa fruticans, Arecaceae): a review. Econ. Bot. 42:206-213.

Humphreys, F.R., Kelley, J. (1961) A method for the determination of starch in wood. Analyt. Chim. Acta. 24:66-70.

Kabyemela, B.M., Adschiri, T., Malaluan, R.M., Arai, K. (1997a) Kinetics of glucose epimerization and decomposition in subcritical and supercritical water. Ind. Eng. Chem. Res. 36:15521558.

Kabyemela, B.M., Adschiri, T., Malaluan, R., Arai, K. (1997b) Degradation kinetics of dihydroxyacetone and glyceraldehyde in subcritical and supercritical water. Ind. Eng. Chem. Res. 36: 2025-2030. 
Kabyemela, B.M., Adschiri, T., Malaluan, R., Arai, K., Ohzeki, H. (1997c) Rapid and selective conversion of glucose to erythrose in supercritical water. Ind. Eng. Chem. Res. 36:5063-5067.

Kabyemela, B.M., Adschiri, T., Malaluan, R., Arai, K. (1999) Glucose and fructose decomposition in subcritical and supercritical water: detailed reaction pathway, mechanisms, and kinetics. Ind. Eng. Chem. Res. 38:2888-2895.

Kosugi, A., Tanaka, R., Magara, K., Murata, Y., Arai, T., Sulaiman, O., Hashim, R., Hamid, Z.A.A., Yahya, M.K.A., Yusof, M.N.M. (2010) Ethanol and lactic acid production using sap squeezed from old oil palm trunks felled for replanting. J. Biosci. Bioeng. 110:322-325.

Liu, C., Wyman, C.E. (2005) Partial flow of compressed-hot water through corn stover to enhance hemicellulose sugar recovery and enzymatic digestibility of cellulose. Bioresource Technol. 96: 1978-1985.

Liu, S. (2010) Woody biomass: niche position as a source of sustainable renewable chemicals and energy and kinetics of hotwater extraction/hydrolysis. Biotechnol. Adv. 28:563-582.

Lu, X., Yamauchi, K., Phaiboonsilpa, N., Saka, S. (2009) Two-step hydrolysis of Japanese beech as treated by semi-flow hot-compressed water. J. Wood Sci. 55:367-375.

Mok, W.S.L., Antal, M.J.Jr. (1992) Uncatalyzed solvolysis of whole biomass hemicellulose by hot compressed liquid water. Ind. Eng. Chem. Res. 31:1157-1161.

Mosier, N., Wyman, C., Dale, B., Elander, R., Lee, Y.Y., Holtzapple, M., Ladisch, M. (2005) Features of promising technologies for pretreatment of lignocellulosic biomass. Bioresource Technol. 96:673-686.

Phaiboonsilpa, N., Yamauchi, K., Lu, X., Saka, S. (2010) Two-step hydrolysis of Japanese cedar as treated by semi-flow hot-compressed water. J. Wood Sci. 56:331-338.

Rydholm, S.A. Pulping Processes. Interscience Publishers, New York, 1965.

Saka, S. (2001) Chemical composition and distribution. In: Wood and Cellulosic Chemistry. 2nd edn. Eds. Hon, D.N-S., Shiraishi, N. Marcel Dekker, New York. pp. 51-81.
Sano, Y., Maeda, H., Sakashita, Y. (1989) Pulping of wood at atmospheric pressure, I. Pulping of hardwoods with aqueous acetic acid containing a small amount of organic sulfonic acid. Mokuzai Gakkaishi 35:991-995.

Sasaki, M., Furukawa, M., Minami, K., Adschiri, T., Arai, K. (2002) Kinetics and mechanism of cellobiose hydrolysis and retro-aldol condensation in subcritical and supercritical water. Ind. Eng. Chem. Res. 41:6642-6649.

Scheller, H.V., Ulvskov, P. (2010) Hemicelluloses. Annu. Rev. Plant Biol. 61:263-289.

Suzuki, S., Rodriguez, E.B., Saito, K., Shintani, H., Iiyama, K. (1998) Compositional and structural characteristics of residual biomass from tropical plantations. J. Wood Sci. 44:40-46.

Timell, T.E. (1967) Recent progress in chemistry of wood hemicelluloses. Wood Sci. Technol. 1:45-70.

Tomomatsu, A., Itoh, T., Wijaya, C.H., Nasution, Z., Kumendong, J., Matsuyama, A. (1996) Chemical constituents of sugar-containing sap and brown sugar from palm in Indonesia. Jpn. J. Trop. Agr. 40:175-181.

Watanabe, M., Aizawa, Y., Iida, T., Levy, C., Aida, T.M., Inomata, H. (2005) Glucose reactions within the heating period and the effect of heating rate on the reactions in hot compressed water. Carbohydr. Res. 340:1931-1939.

Yoshida, K., Kusaki, J., Ehara, K., Saka, S. (2005) Characterization of low molecular weight organic acids from beech wood treated in supercritical water. Appl. Biochem. Biotechnol. 121-124: 795-806.

Yu, Y., Lou, X., Wu, H. (2008) Some recent advances in hydrolysis of biomass in hot-compressed water and its comparisons with other hydrolysis methods. Energ. Fuel. 22:46-60.

Received September 1, 2010. Accepted December 28, 2010.

Previously published online February 9, 2011. 